\title{
Salinity on the southeastern Dundas Tableland, Victoria
}

\begin{abstract}
Historical evidence of early salinity, vegetation and landuse changes, and pedological studies have been used in formulating a new model for salinity processes acting on the Dundas Tableland in southwestern Victoria. Contrary to previous assumptions, salinity in this area was a feature of the preEuropean landscape and was noted in the earliest surveys and journals. Analysis of historical records show an initial post-settlement increase in the tree numbers, followed by a rapid decline much later than previously assumed. Accumulation of salts in the regolith may be attributed to marine incursions during the Miocene and Pliocene, the extensive weathering to develop a deep regolith, and windblown and cyclic salt accumulation. A trend analysis of historical streamflow and bore hydrograph records does not indicate rising groundwater levels. The pedological features of duplex and sodic soil profiles support a history of prolonged seasonal waterlogging. A model with seasonal lateral flow of water through the upper regolith can better account for the spread of salinity than the rising groundwater hypothesis. By control of waterlogging, land managers could improve soil structure, enhance root growth and soil water use, as well as inhibit the spread of salinity.
\end{abstract}

KEY WORDS: Dundas Tableland, environmental history, hydrogeology, salinisation.

\section{INTRODUCTION}

On a global scale, it has been estimated that 10 ha of arable land are lost every minute, and that 3 ha of these are lost to salinisation (Ghassemi et al. 1995). Soil salinisation is the process by which the soluble salt content in soil profiles becomes so great as to adversely affect pasture or crop growth. In Australia, dryland (non-irrigated) salinity accounts for approximately half of the problem (Table 1). Hence soil salinisation and the associated land degradation are popularly regarded as Australia's most serious environmental problem.

From the earliest Victorian reports on soil degradation (Holmes et al. 1939), salinity was related to land clearance and researchers adopted a water-balance framework. The Australian basis for this derives from Western Australian literature of the 1920s and 1930s by Wood and Teakle (quoted in George et al. 1997; Soil Conservation Authority 1978). Cope's (1958) investigation is considered the earliest survey of salt-affected areas in Victoria (Nathan 1998). He concluded that the extent of salting ( $>4000$ ha) was greater than generally realised. The concern of landholders that salt-affected land was increasing was acknowledged.

Cope (1958) regarded rainwater as the main source of salt. He believed that surplus rainwater was mobilising the soluble salts stored in the permeable A-horizon of soil, causing it to accumulate above an impermeable clay B-horizon and discharge downslope or on the valley floor. Cope argued that before European settlement the rainwater was used by trees where it fell, although he acknowledged that some saline discharge took place. As with most studies, the time frame associated with the tree loss was ill-defined, simply 'following settlement'.

In the late 1970s two important reports (Soil Conservation Authority 1978; Jenkin 1979) represent a major turning point in Victorian salinity studies. These identified saline groundwater as the main and immediate (rather than ultimate) source of salt, and that several metres of recharge had been added to the aquifers since settlement. This rise in groundwater levels was linked with the spread of salinity. Geology, rather than agricultural science, was then promoted as the most appropriate research base from which to investigate dryland salting using hydrogeology, geomorphology and soil science (Jenkin 1983).

Most dryland salinity research in the Victorian Highlands throughout the 1980s and 1990s has focused on quantifying the hydrologic balance, especially groundwater recharge (Clifton \& Taylor 1996). Although there have been changes in thinking as to the sources of the salt and its mobilisation, two cornerstones of the waterbalance framework have remained unchallenged for fifty years. These were that hydrologic imbalance began with European settlement, and that this imbalance caused salinity.

\section{Predictive modelling}

Numerical modelling of hydrologic changes is commonly used to predict the impact of salinisation. Success requires a conceptual model (Hatton 1998) that includes all components of the hydrological system: inputs, outputs, pathways, extents, stresses, time steps and processes. The model must be based on an understanding of the interaction of water with its physical, chemical and biological environment. Knowledge of the catchment geology, regolith and soil in three dimensions provides the basic framework for the best conceptual models. However, the hydrological changes within the catchment must also be placed into historical context, and include Quaternary climate, preEuropean landscapes, and land-use changes associated with European settlement. 
Table 1 Extent of dryland salinity in Australia (Coram 1998).

\begin{tabular}{lrc}
\hline & Salinised area (ha) & Year \\
\hline Western Australia & 1804450 & 1994 \\
South Australia & 391900 & 1996 \\
Victoria & 120000 & 1994 \\
New South Wales & 120000 & 1996 \\
Tasmania & 20000 & - \\
Queensland & 10190 & 1991 \\
Northern Territory & negligible & 1994 \\
Total & 2466540 & - \\
\hline
\end{tabular}

Published examples of complete conceptual models for dryland salinity in highland areas are much less common than for irrigation-induced salinity in lowland areas. In a report which proposes a national framework to characterise salinisation processes, only 15 conceptual hydrogeological models are presented for the whole of Australia (Coram 1998). These models are based solely on their geological setting and ignore landscape development, pedological or historical factors.

By contrast, in the Yass River catchment of New South Wales, extensive research (Jankowski \& Acworth 1993, 1997; Acworth et al. 1997) has produced a model in which Pleistocene debris-flow deposits play a major role in the distribution and severity of salinisation. These deposits contain salt-rich aeolian dust (parna) which has accumulated on the valley sides and been transferred to the floors by mudflows. The onset of dryland salinity occurred before widespread clearing of the landscape, possibly associated with drier climates, or the earliest clearing of deep-rooted vegetation. The hydrological change has resulted in groundwater discharge through the debris-flow deposits causing the observed salinity. This conceptual model explains the spatial occurrence of dryland salinity in the Yass River catchment and has direct relevance for land managers, since it proposes that salinity is a problem only on the debris-flow clays that underlie groundwater discharge locations.

Dryland salinity in the Bulart area of the southeastern Dundas Tableland (Figure 1), about $20 \mathrm{~km}$ north of Hamilton, Victoria, has been a growing concern for the landholders (MacEwan \& Dahlhaus 1996) due to the decline in pasture productivity. In this area salinity affects $5 \%$ of the productive agricultural land (Jerinic 1993) and research was initiated by the farmers' requests for practical advice on saline-land management. Conceptualisation of the salinity processes at Bulart requires the integration of the history of landuse, geology and landscape development, regolith and soil development, and hydrology.

\section{HISTORICAL EVIDENCE OF SALINITY}

Dryland salinity on the Dundas Tableland has long been considered to be secondary (that is, to have developed following European settlement). This assumption seems to derive from squatter John Robertson's observations (quoted in Bride 1898) of the saline springs killing the native grasses in the Dundas area only 19 years after settlement

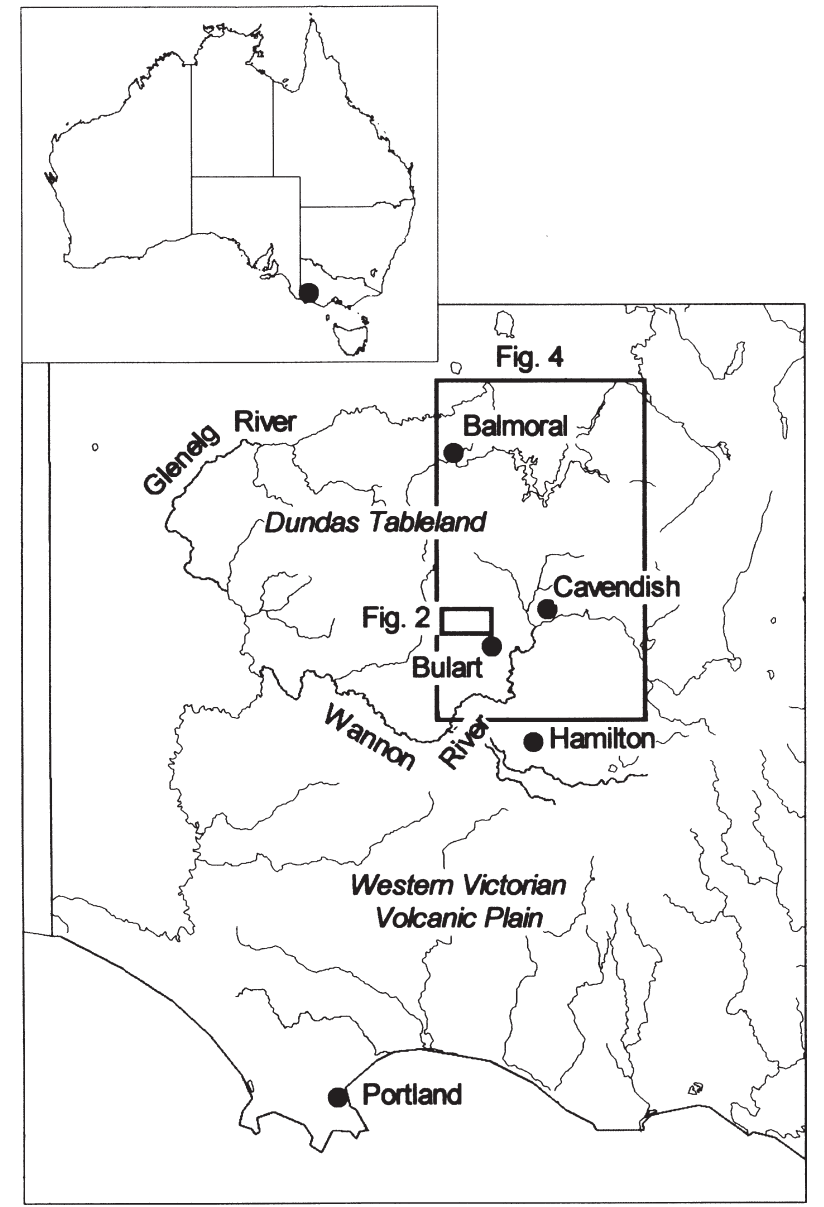

Figure 1 Locality map, showing location of Figures 2 and 4. The Dundas Tableland is encircled by the Glenelg and Wannon Rivers.

(Jenkin 1979, 1983). It is questioned for a number of reasons (Nathan 1998, 1999).

Early cartographic evidence indicates that some streams were saline at the time of European settlement. The area of the Koroite Rivulet map (Historical Plans Glenelg 1843) shown in Figure 2 was not held under a squatting license at the time of survey, or if so, was unoccupied. Similarly, a survey in early spring of 1842 of the Wannon River, adjacent to present-day Cavendish, recorded it to be brackish in some holes. Surveys of the Glenelg River and its tributaries from the late 1840s (Historical Plans Glenelg 1848-1852) clearly specify freshwater areas, which implies that poor quality water is also present. In addition, casual references to the saline nature of the summer water supply in the Glenelg and Wannon Rivers, and to saline groundwater, are noted in the newspapers, letters and diaries of the first European settlers (e.g. the Corney Diary 1857-1871, quoted in Nathan 1998).

To a considerable extent, the 'problem' of salinity is a function of the changing scale of land tenure. Salinity was not perceived as a problem until land subdivision significantly reduced the size of tenure units. During the 1920s, and again in the 1950s, the number of holdings on the Dundas Tableland increased, through both the closer settlement and soldier settlement policies. It is 


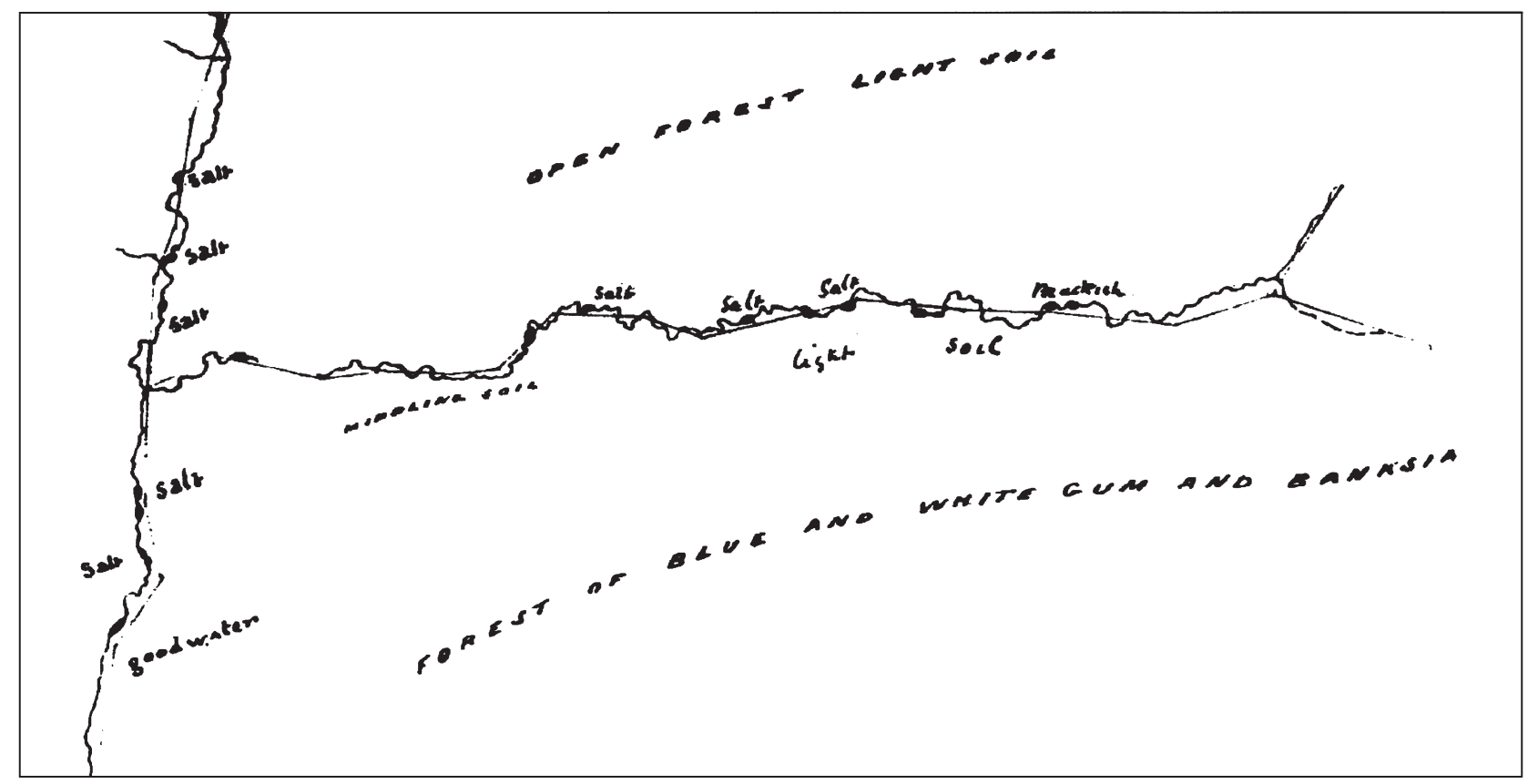

Figure 2 Detail from 'Survey of Koroite Rivulet part of the River Wannon or Karrawalla and some of the tributary' 1843 showing salt springs (Historical plans Glenelg 1843). See Figure 1 for location.

possible that the actual extent of saline land had not increased significantly from the 1870 s to the 1950 s, but that the existing salted sites became more obvious to the new landholders.

The central component of the conventional risinggroundwater model is the increased recharge (or decreased evapotranspiration) due to changing vegetation. Yet, despite the importance given to tree clearance, it has rarely been located in historical time. Several changes in tree cover do have some historical validity (Nathan 1998, 1999) and should be considered in any model that invokes reducing evapotranspiration and increasing recharge.

The banksia (Banksia marginata) was formerly the most widespread tree on the tableland, with red gum (Eucalyptus camaldulensis), swamp gum (E. ovata), manna gum (E. viminalis), stringybark (E. baxteri), casuarina (Allocasuarina verticillata) and possibly cherry (Exocarpos cupressiformis) also significant. The number of red gums per hectare increased during the decades of earliest settlement (1840-1870), relative to previous and later time periods (Figure 3). A change in fire regime with the abandonment of the Aboriginal peoples' practice of burning the landscapes, or 'firestick farming' (Pyne 1991), had allowed eucalypt regeneration.

The diversity of tree species had declined by the end of the nineteenth century, due to the change from Aboriginal to European land management and the introduction of exotic grazing species.

During 1920-1950 there was a rapid decline in the average number of red gums per hectare, mostly due to timber cutting (Figure 3). Milling records of tree lengths and girths indicate that the majority of trees were less than 70 years old. Since the 1890s the variety and density of pasture species has also declined, with the gradual transition from the predominantly native pastures (pre-1950) to more exotic species.

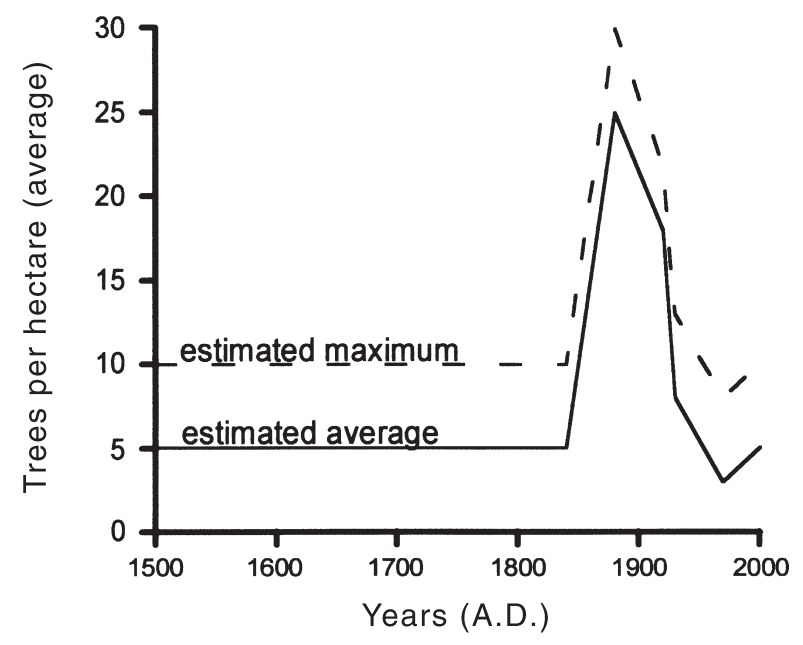

Figure 3 Estimated changes in number of trees per hectare, eastern Dundas Tableland (based on Nathan 1998, 1999).

\section{GEOLOGICAL SETTING AND LANDSCAPE DEVELOPMENT}

The eastern Dundas Tableland is composed of Palaeozoic rocks overlain by flat-lying Cenozoic deposits, which obscure much of the basement geology (Figure 4). Most of the Palaeozoic rocks belong to the Glenelg structural zone, part of the Adelaide (or Delamerian) Fold Belt (Cayley \& Taylor 1998).

\section{Palaeozoic}

The oldest rocks are Cambrian sedimentary and volcanic rocks, metamorphosed to high grades and intruded by Cambro-Ordovician granites west of the Yarramyljup Fault, and metamorphosed to low grades east of this fault 


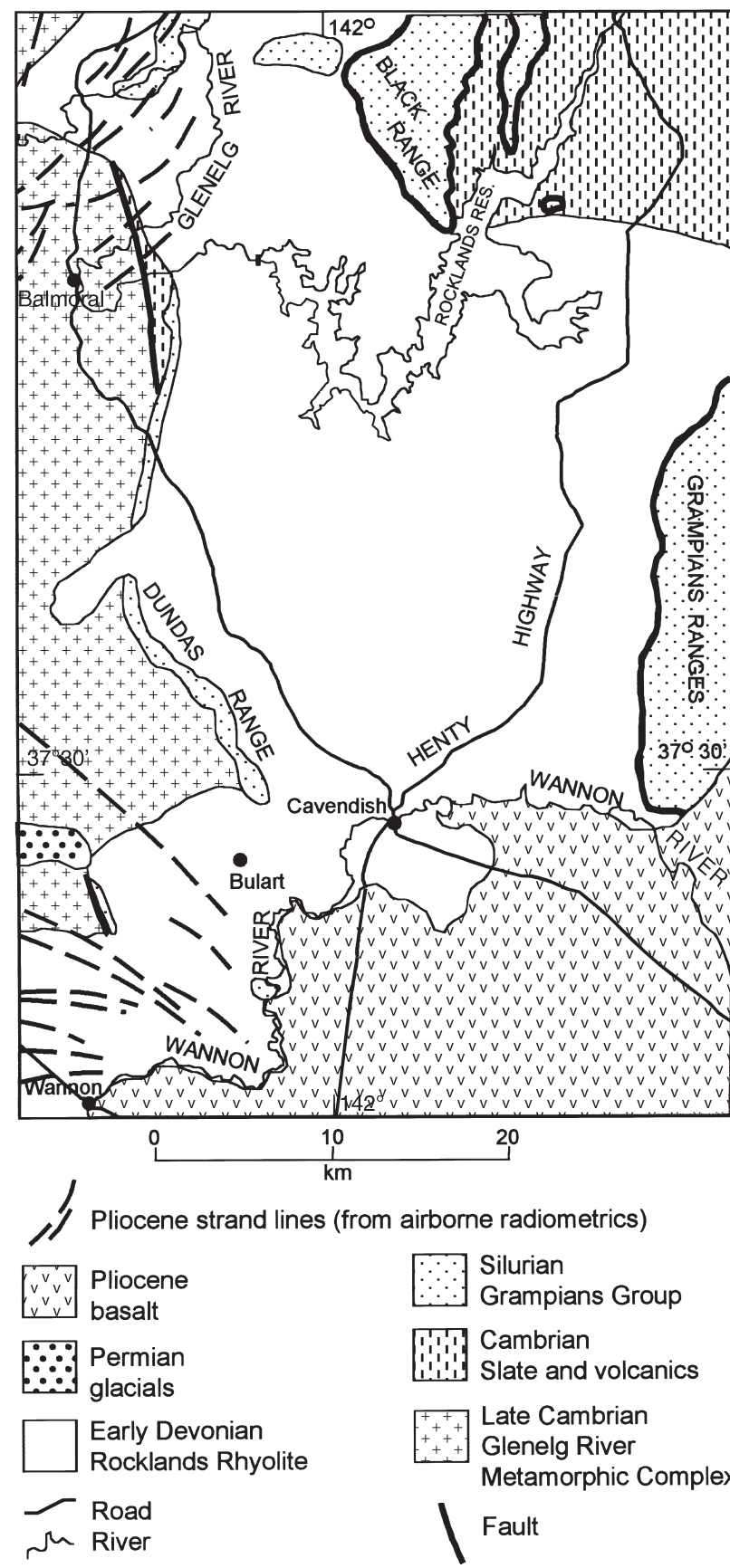

Figure 4 Geology of the eastern Dundas Tableland. All units except the Pliocene basalt and the Grampians Group in the Grampians, Black and Dundas Ranges are covered by ferruginised regolith, with the older rocks exposed mainly in stream valleys. See Figure 1 for location.

(Gibson \& Nihill 1992). Overlying the metamorphic rocks are the Silurian Grampians Group and the Lower Devonian Rocklands Rhyolite. The Grampians Group comprises quartzose sandstone and minor shale (Spencer-Jones 1965; Cayley \& Taylor 1997).

Much of the eastern Dundas Tableland is underlain by the Rocklands Rhyolite (Figure 4), composed of several flows of subaerial ignimbrite and lava. It is essentially flatlying and is up to $250 \mathrm{~m}$ thick (Simpson 1996). The undeformed nature and horizontal attitude of the Rocklands
Rhyolite indicates that no folding has affected the region since the Late Silurian to Early Devonian.

Elements of the present landscape were already in place in the Devonian period. It appears that the Grampians, Black and Dundas Ranges existed during the Early Devonian, when the rhyolites were erupted, and there is no evidence that the Rocklands Rhyolite was ever covered by a significant thickness of younger rocks. Fission track dating of apatite (Gleadow \& Lovering 1978; Foster \& Gleadow 1992) also attests to the antiquity of the landscape, with rocks in the area having been close to the surface since the Middle Devonian.

\section{Mesozoic}

From the Middle Devonian to the Cretaceous the eastern Dundas Tableland was apparently above sea-level, with little deposition or erosion. During the Cretaceous the tableland may have been covered by the fluvial Merino Group, which fills much of the Otway Basin to the immediate south, but most of these sedimentary rocks were stripped off before the Miocene. Alternatively, the tableland came into existence at this time and received no sediments except around its northwest and southern boundaries.

\section{Cenozoic}

Paleocene and Eocene sediments have not been identified on the Dundas Tableland, suggesting there was no deposition during this time and that the area was above sealevel. However, an Oligocene to Miocene transgression laid down the Heytesbury Group limestone (Abele et al. 1988) over at least part of the tableland. Richly fossiliferous limestone of the Heytesbury Group occurs just south of the area on Figure 4. It forms a layer up to $20 \mathrm{~m}$ thick and occurs along the southern and northwestern edges of the Dundas Tableland. This marine unit is more widespread to the south, in the Otway Basin, and to the north in the Murray Basin (where it is known as the Duddo Limestone) (Abele et al. 1988). Its absence over most of the Dundas Tableland could imply that this was a regional high before the Miocene. However, moulds of Late Oligocene to midMiocene marine fossils (Proxichione and Annachlamys) have been found in the ferruginised gravels at Englefield, about $8 \mathrm{~km}$ south of Balmoral, near the centre of the tableland (Paine 1995). This, and the more recent discovery of fragments of marine fossils (echinoids) in ferruginised sediments at Wannon Quarry, on the southern boundary of the tableland (M. D. Paine pers. comm. 1999), raises the possibility that the whole tableland may have been submerged during this time interval.

A further incursion of the sea into the tableland from the north and south, probably during the Pliocene, postdated and exceeded that of the Heytesbury Group. It is recorded by a series of parallel strandlines that can be seen on airborne radiometric images. These strandlines, characterised by high $U$ and Th values, are not shown on existing maps. They form arcuate features, which cover much of the northern Dundas Tableland and some of its southern part between Bulart and Hamilton, and are concordant with similar features in the Murray Basin to the north (Blackburn 1962) and in the Otway Basin to the south. They 
belong to the Pliocene Dorodong Sand, an equivalent of the Parilla Sand of the Murray Basin (Abele et al. 1988). As the strandlines do not reach the centre of the tableland, it appears that the tableland was a topographic high at the time.

Sea-level falls during the Pleistocene would have exposed most of western Victoria to subaerial conditions and caused incision of the Glenelg and Wannon river systems. However, uplift of the Dundas Tableland, including parts covered by strandlines, to $200-250 \mathrm{~m}$ above sealevel must have occurred after the strandlines were deposited, making the rise Pliocene or younger. This youngest uplift has probably generated most of the stream incision seen in the western Dundas Tableland.

Headward erosion has not yet reached the eastern part of the tableland, which contains the upper reaches of the Glenelg and Wannon Rivers. The southern part of the eastern Dundas Tableland has been covered by PlioPleistocene basalt flows of the Newer Volcanics. These buried the ancestral Wannon River and caused it to reorient itself along the northern edge of the flow (Fenner 1918).

\section{Regolith development}

Most of the Dundas Tableland was affected by intense weathering in the Late Cenozoic, resulting in a deep regolith profile over most Palaeozoic, Mesozoic and Lower Cenozoic rocks. The youngest Cenozoic units present, the quartz sandstone and strandlines of the Dorodong Sand, are strongly ferruginised, indicating that weathering continued into the Quaternary.

Aspects of regolith development on the Dundas Tableland have been described in previous research (Bourman 1993a, b; Paine 1995; Perry 1996; Quinn 1997). Continuous deep weathering has left a distinctive profile characterised by a basal pallid, kaolinitic saprolite that exhibits isovolumetric alteration, preserving the original rock structures. This is overlain by a mottled zone and a ferruginised upper zone, which was previously referred to as a laterite (Spencer-Jones 1965). Bourman (1993b) cautions against this usage, since the formation of ferricrete in the upper profile suggests lateral rather than vertical accumulation of iron (Bourman 1993a). The mottled zone has formed in situ (Bird \& Chivas 1993; Paine 1995) based on oxygen-isotope composition.

Although further work is required, the continual weathering model (Bourman 1993a) seems to be the most applicable to the Dundas Tableland. In this model, iron has been redistributed by regional fluctuating groundwater and lateral transport through perched water-table movements.

This sequence of landscape development has provided opportunities for salt accumulation in the deeply weathered profile. Much of it may have simply been blown in from the nearby sea. The salinity of rainfall in southeastern Australia has been measured in numerous studies (Anderson 1945; Hutton 1976; Blackburn \& MacLeod 1983) most of which have correlated salt load in rainfall with distance from the ocean. For lengthy periods during the Miocene and Pliocene, salts may have been added to the regolith during marine regressions or as windblown accessions from the adjacent coast.
Considerable volumes may have been added as saline dust derived by deflation from saltpans in the adjacent Murray Basin (Evans 1998). In addition, the dissolution of minerals by groundwater during weathering can be a source of salts. The continued and intensive weathering of the ignimbrite and granite has been shown elsewhere to be correlated to salt accumulation (Gunn 1985). One study (Brouwer \& Van de Graaff 1988) estimated a salt store on the Dundas Tableland of $500 \mathrm{t} / \mathrm{ha}$, all of which they attributed to cyclic accumulation (i.e. from rainfall).

\section{SOILS OF THE BULART AREA}

Soil mapping carried out by Perry (1996) and Robinson (1999) revealed eight soil series mappable at 1:25000 scale. Of these, six units are strongly duplex (Northcote 1979) showing marked textural contrast between generally hard setting, apedal topsoils and mottled, pedal clay subsoils. Bleached A2 horizons and accumulations of buckshot and ironstone gravel are not uncommon.

The duplex soils generally exhibit much lower hydraulic conductivities in their subsoils than in their topsoils, and are consequently prone to waterlogging as well as restricting deep root growth of crops or pastures (Tennant et al. 1992). Duplex soil profiles have been attributed to sedimentary layering or to extreme weathering with clay illuviation (Chittleborough 1992), but the evidence of thick clay skins in the Bulart soils indicates that the latter process has dominated here.

The remaining two soil series comprise a minor mapping unit of lunette soil, and a larger complex of alluvial soils that have been recently deposited and show mostly uniform and gradational texture profiles. Salinity in the Bulart area is mostly confined to these alluvial soil units, the swamp soils (duplex) and the lower slopes of other duplex soil series.

\section{Sodicity}

Besides the hydraulic 'throttle' to downward water movement as a result of fine texture in the duplex subsoils, soils in the region further restrict water movement through their sodicity. Soil sodicity has long been known to affect waterlogging, root growth and soil aeration (Northcote \& Skene 1972). In Victoria $66 \%$ of the land sown to dryland pastures has sodic soils (Ford et al. 1993) and most of the Dundas Tableland would fall into this classification.

Soils are classified as 'sodic' in Australia if sodium constitutes $6 \%$ or more of the exchangeable cations within the clay-organic exchange complex. Such soils tend to be dispersive, meaning that clay particle aggregates may disintegrate completely (deflocculate) in saturated conditions. Hence they lose macroporosity over time, as dispersed clay moving in suspension fills pores in the subsoil. Data collected by Woof (1994) illustrate the high level of sodicity in the Bulart soils (Table 2). Soils with an exchangeable sodium percentage of over 25 are regarded as extremely sodic or 'hypernatric' (Isbell 1996). 
Table 2 Salinity (electrical conductivity) and sodicity (exchangeable sodium percentage) of soils from the Bulart area (Woof 1994).

\begin{tabular}{llccc}
\hline Sample no. & Soil texture & $\begin{array}{c}\text { Depth } \\
(\mathrm{m})\end{array}$ & $\begin{array}{c}\text { Electrical conductivity } \\
\left(\mathrm{dSm}^{-1}\right)\end{array}$ & $\begin{array}{c}\text { Exchangeable sodium } \\
\text { percentage }\end{array}$ \\
\hline EL100 & gravelly clay & 1.00 & 0.29 & 26 \\
IV250 & clayey sand & 2.50 & 0.67 & 30 \\
IX100 & sandy gravel & 1.00 & 0.11 & 33 \\
KB150 & clay & 1.50 & 0.10 & 8 \\
KM300 & clay & 3.00 & 0.29 & 21 \\
RD180 & clay & 1.80 & 0.35 & 20 \\
RD50 & clay & 0.50 & 0.38 & 19 \\
RN18 & medium gravel & 0.18 & 0.12 & 17 \\
RN300 & clay & 3.00 & 1.15 & 33 \\
WB150 & silty clay & 1.50 & 0.57 & 38 \\
\hline
\end{tabular}

aElectrical conductivity of a 1:5 soil to water suspension.

\section{HYDROGEOLOGY}

The Rocklands Rhyolite and overlying weathered regolith comprise the main aquifers in the Bulart area. However, the boundary conditions of this fractured-rock aquifer are currently unknown. The nature of the Yarramyljup Fault, the extent of the easterly dipping (i.e. underlying) Grampians Group sandstone and the nature of its boundary with the Cambrian sedimentary rocks have yet to be determined. One hypothesis currently being investigated is that the east-dipping quartzose sandstone acts as a partially confined, upwardly leaking aquifer, recharging the ignimbrite from below.

The groundwater levels and salinity in the ignimbrite and the regolith have been monitored since 1993 in over 70 bores in the Bulart area. Studies of the groundwater chemistry (Woof 1994) indicate a uniform hydrosome (Figure 5), suggesting a single, connected, fractured-rock aquifer made up of the ignimbrite and the lower regolith. The major ion composition approaches that of seawater (Figure 5), conforming to the normal hydrochemical evolution of a hydrosome (Stuyfzand 1999).

Seasonal variation in groundwater level is observed, but no trend (rise or fall) is evident in the short hydrograph record. In the bores constructed after the introduction of groundwater regulations, current standing water levels are similar to those recorded at the time of drilling (from 1968), suggesting no significant change has occurred during the past 30 years. Similarly, observation bores at Gatum, $15 \mathrm{~km}$ north of Bulart, record a slight fall in water levels over the past 20 years (Heislers 1998).

An unusually long and continuous record of streamflow data exists for the Glenelg River near Balmoral (gauging station number S.I. No 238201). Although complicated by the regulation of stream flows since the Moora diversion scheme in the 1920s and the construction of Rocklands Reservoir in 1950, the record provides information on groundwater discharge. An analysis of this record for the pre-dam period was undertaken using a parametric method, the Generalised Additive Model (Nathan et al. 1999) to estimate time trends (Figure 6).

The trend line represents the decrease in stream flow over a period of 60 years, with the influence of the climate removed (R. J. Nathan pers. comm. 1999). These data incorporate the period of most active tree clearance and pasture depletion, from the 1920s. The trend line shows the

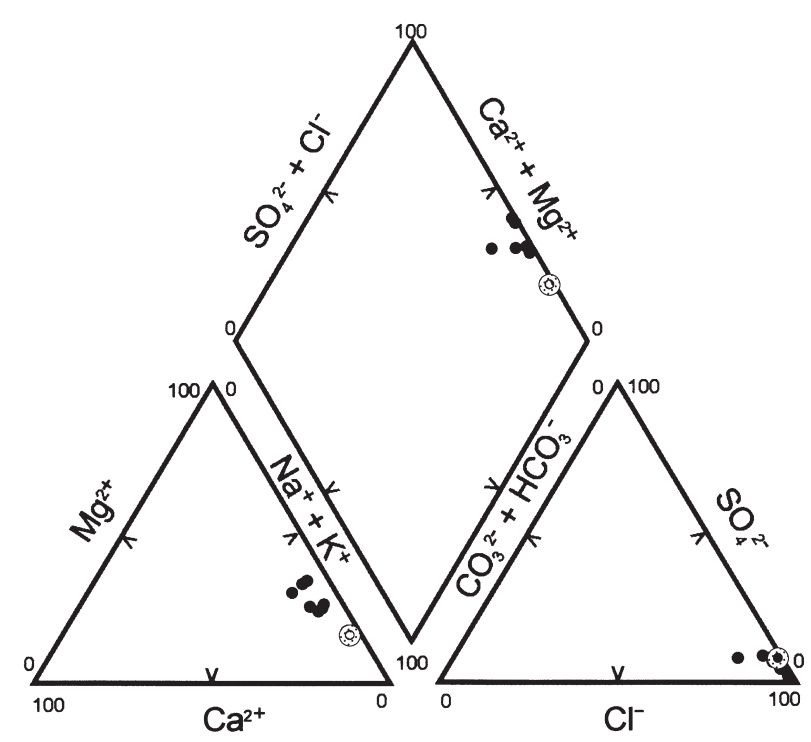

Figure 5 Piper plot of groundwater chemistry from eight spatially variable bores at Bulart (data from Woof 1994). Seawater is plotted as an open circle (data from Richter \& Kreitler 1993).

streamflow (i.e. runoff and groundwater baseflow) beginning to decrease in the early 1900s and remaining in steady decline for fifty years. If the accuracy of the trend analysis is assumed, it does not support rising groundwater levels through tree clearing.

Features of the regolith and geomorphology indicate that shallow water-tables have been present on the Dundas Tableland since long before European settlement. The redoximorphic features of the blocky structures in the regolith profile show iron-depleted (bleached) rims surrounding an iron-rich core (Dahlhaus \& MacEwan 1997). This mottling pattern is attributed to prolonged seasonal waterlogging of the upper profile, during which iron was transferred from the outer rim under reducing (saturated) conditions and deposited under oxidising (unsaturated) conditions in the inner core (Bourman 1993a). The presence of swamps, some with sizeable clayey lunettes, provides geomorphic evidence of past waterlogging at Bulart (Perry 1996). Clayey lunettes require high saline water-tables and a dry lake bed for at least part of the year for their formation (Macumber 1968). 
Investigation of the hydraulic properties of the upper regolith using large diameter $(300 \mathrm{~mm})$ intact cores (Fawcett 1996) confirmed the role of lateral water flow in salinity and waterlogging (Dahlhaus \& MacEwan 1997; Fawcett \& Dahlhaus 1998). In this model (Figure 7), infiltration of rainwater quickly backfills the vertical pathways in the regolith and ponds in the upper regolith. Horizontal flow commences in the saturated mid to upper regolith and the resulting interflow moves downslope. Lower hydraulic conductivity of the regolith profile on the lower slope forces some water to the surface as return flow, adding to surface runoff.

Since the removal of the vegetation from the landscape, the increase in infiltration has resulted in lengthier seasonal waterlogging and increased volume of interflow. At Gatum, Brouwer and Fitzpatrick (1998) have demonstrated a strong relationship between current duration of water saturation and Munsell soil colour (value and chroma) of the upper soil profile. Their work confirms that changes to regolith hydrology have occurred in recent times. However, the removal of native species from the landscape has added little to groundwater recharge. The relatively stable trend in annual groundwater levels indicates that the groundwater system is dischargedriven.

\section{CONCLUSIONS}

A model in which the existing (primary) salinity has been spread through soil waterlogging (Figure 7) can account for the observed increase in salt-affected areas (Dahlhaus \& MacEwan 1997). The alternative model, which assumes that early settlers cleared the landscape and that the subsequent increase in recharge has raised groundwater levels, cannot be supported by the evidence.
Figure 6 Trend analysis of streamflow of the Glenelg River near Balmoral, before construction of the Rocklands Dam. The declining trend in streamflow occurs during the period of rapid vegetation removal (General Additive Model analysis by R. J. Nathan).

Figure 7 Conceptual model for salinisation process at Bulart (Dahlhaus \& MacEwan 1997)
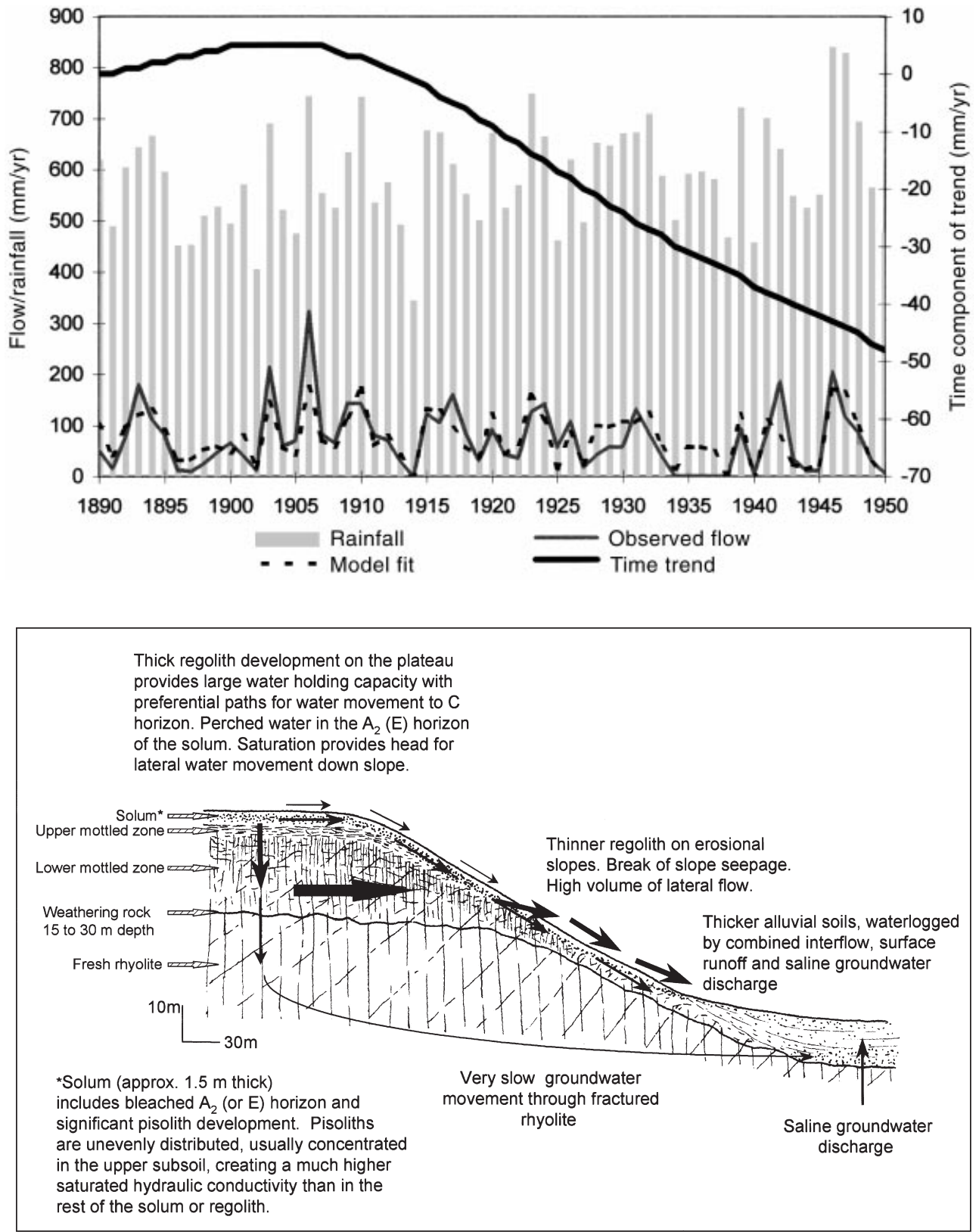
Because waterlogging reduces land productivity, and increases throughflow and the area of salt-affected land, it must be seen that regional soil management is of great immediate importance. Efforts should be directed towards improving soil structure and root growth, and decreasing waterlogging. The latter may be achieved either through direct soil improvements or the installation of agricultural drainage (MacEwan et al. 1992; McFarlane \& Cox 1992).

Rising groundwater resulting from tree clearing is the commonly assumed cause of salinity in Australia (Clifton \& Taylor 1996; Coram 1998). However, the multidisciplinary study of salinity on the Dundas Tableland has challenged this narrow approach. By broadening the investigative base of the salinity problem to embrace integrated input from several disciplines, a more holistic conceptual model has emerged.

\section{ACKNOWLEDGEMENTS}

The generous assistance and support of the members of the Bulart Land Management Group is gratefully acknowledged. R. J. Nathan is thanked for the analysis of streamflows, and T. Darragh and S. Carey for fossil identification. The constructive comments provided by G. H. McNally and I. R. Acworth were of great benefit to the manuscript.

\section{REFERENCES}

Abele C., Gloe C. S., Hocking J. B. et AL. 1988. Tertiary. In: Douglas J. G. \& Ferguson J. A. eds. Geology of Victoria, pp. 251-350. Geological Society of Australia, Victorian Division, Melbourne.

Acworth R. I., Broughton A., Nicholl C. \& JANKowski J. 1997. The role of debris-flow deposits in the development of dryland salinity in the Yass River catchment. Hydrogeology Journal 5, 22-36.

AnDERSON V. G. 1945. Some effects of atmospheric evaporation and transpiration on the composition of natural water in Australia. Australian Chemical Institute Journal 12, 41-98.

BIRD M. I. \& ChIVAS A. R. 1993. Geomorphic and palaeoclimatic implications of an oxygen isotope chronology of Australian deeply weathered profiles. Australian Journal of Earth Sciences 40, 345-358.

BLACKBURN G. 1962. Stranded coastal dunes in northwestern Victoria. Australian Journal of Science 24, 388-389.

BlackBuRN G. \& MACLEOD S. 1983. Salinity of atmospheric precipitation in the Murray-Darling Drainage Division, Australia. Australian Journal of Soil Research 21, 411-434.

BOURMAN R. P. 1993a. Modes of ferricrete genesis: evidence from southeastern Australia. Zeitschrift für Geomorphologie 37, 77-101.

Bourman R. P. 1993b. Perennial problems in the study of laterite: a review. Australian Journal of Earth Sciences 40, 387-401.

BRIDE T. (Editor) 1898. Letters from Victorian Pioneers. Heinemann, Melbourne.

Brouwer J. \& FitzPATRICK R. 1998. Relations between soil macromorphology and current soil hydrology in a toposequence in SE Australia. Proceedings of the International Soil Science Society Congress, Montpellier, France, 20-26 August 1998: Symposium 15, 8 pp (CD-ROM).

Brouwer J. \& VAN DE GRAAFF R. H. M. 1988. Readjusting the water balance to combat dryland salting in southern Australia: changing the hydrology of a texture contrast soil by deep ripping. Agricultural Water Management 14, 287-298.

CAYley R. A. \& TAYloR D. H. 1997. Grampians special map area geological report. Geological Survey of Victoria Report 107.

CAYley R. A. \& TAYLOR D. H. 1998. The Lachlan margin, Victoria: the Moyston Fault, a newly recognised terrane boundary. Geological Society of Australia Abstracts 49, 73.

Chittleborough D. J. 1992. Formation and pedology of duplex soils. Australian Journal of Experimental Agriculture 32, 815-825.
Clifton C. \& TAYLoR J. (Editors) 1996. South west research and investigation strategy review. Workshop proceedings. Department of Natural Resources and Environment, Victoria.

Cope F. 1958. Catchment Salting in Victoria. Soil Conservation Authority of Victoria.

CORAM J. 1998. National classification of catchments for land and river salinity control. Water and salinity issues in agroforestry No.3. Rural Industries Research and Development Corporation Publication 98/78.

DAhLhaus P. G. \& MAcEWAN R. J. 1997. Dryland salinity in south west Victoria: challenging the myth. In: McNally G. H. ed. Case studies in engineering geology, hydrogeology and environmental geology, pp. 165-177. Geological Society of Australia, Environmental, Engineering, Hydrogeology Specialist Group Papers Series 3.

Evans W. R. 1998. What does Boorowa tell us? Salt stores and groundwater dynamics in a dryland salinity environment. In: Groundwater Sustainable Solutions, Proceedings of IAH conference, Melbourne, pp. 267-274.

FAWCETT J. D. 1996. A hydrological investigation of soil water logging in the Bulart region, southeastern Dundas Tablelands. BAppSci (Hons) thesis, University of Ballarat, Ballarat (unpubl.)

FAWCETT J. D. \& DAhlhaus P. G. 1998. Regolith hydrology of the Dundas Tablelands - an investigation of soil-water logging and salinity. Geological Society of Australia Abstracts 49, 138

Fenner C. 1918. The physiography of the Glenelg River. Proceedings of the Royal Society of Victoria 30, 99-120.

Ford G. W., Martin J. J., Rengasamy P., Boucher S. C. \& Ellington A. 1993. Soil sodicity in Victoria. Australian Journal of Soil Research 31, 869-909.

Foster D. A. \& GLEADOW A. J. W. 1992. Reactivated tectonic boundaries and implications for the reconstruction of southeastern Australia and northern Victoria Land, Antarctica. Geology 20, 267-270.

George R., McFARLAnE D. \& Nulsen R. 1997. Salinity threatens the viability of agriculture and ecosystems in Western Australia. Hydrogeology Journal 5, 6-21.

Ghassemi F. A., Jakeman A. J. \& Nix H. A. 1995. Salinisation of Land and Water Resources. University of New South Wales Press and CAB International,Wallingford, UK.

Gibson G. M. \& Nihill D. N. 1992. Glenelg River Complex: western margin of the Lachlan Fold Belt or extension of the Delamerian Orogen into western Victoria? Tectonophysics 214, 69-91.

Gleadow A. J. W. \& Lovering J. F. 1978. Thermal history of granitic rocks from western Victoria: a fission-track dating study. Journal of the Geological Society of Australia 25, 323-340.

GuNN R. H. 1985. Shallow groundwaters in weathered volcanic, granitic and sedimentary rocks in relation to dryland salinity in southern New South Wales. Australian Journal of Soil Research 23, 355-371.

HatTon T. J. 1998. Catchment Scale Recharge Modelling. CSIRO Publishing, Collingwood.

HeISLERS D. 1998. Glenelg groundwater monitoring update. Centre for Land Protection Report. Department of Natural Resources and Environment, Victoria.

Historical Plans Glenelg 1843. Koroite Rivulet (no. 34 \& 34a). Surveyor unknown. Crown lands and survey, Land and Survey Information Centre, Melbourne.

Historical Plans Glenelg 1848-1852. General survey of the Rivers Glenelg, Chetwynd, Pigeon Ponds. Surveyor: H. Wade. Crown lands and survey, Land and Survey Information Centre, Melbourne.

Holmes L., LeEPer G. \& Nicolls K. 1939. Survey of the country around Berwick. Proceedings of the Royal Society Victoria. 52, 177-238.

Hutton J. T. 1976. Chloride in rainwater in relation to distance from ocean. Search 7, 207-208.

IsBELl R. F. 1996. The Australian Soil Classification. CSIRO, Melbourne.

JANKOWSKI J. \& ACWORTH R. I. 1993. The hydrochemistry of groundwater in fractured bedrock aquifers beneath dryland salinity occurrences at Yass NSW. AGSO Journal of Australian Geology \& Geophysics 14, 279-286.

JANKOWsKI J. \& AcWORTH R. I. 1997. Impact of debris-flow deposits on hydrogeochemical processes and the development of dryland salinity in the Yass River catchment NSW. Hydrogeology Journal $5,71-88$.

JERINIC F. L. 1993. A hydrogeological study of dryland salinity in the Bulart region, western Victoria. BAppSci (Hons) thesis, Ballarat University College, Ballarat (unpubl.).

JENKIN J. J. 1979. Dryland salting in Victoria. Soil Conservation Authority of Victoria. 
JENKIN J. J. 1983. Dryland salinity symposium-introduction Proceedings of the Royal Society of Victoria 95, 101-102.

MacEwan R. J. \& Dahlhaus P. G. 1996. Raising the profile with Western District farmers - soils training for the landholder. In Soil Science-Raising the Profile, Vol. 2, pp. 157-158. Proceedings of the Australian and New Zealand Soil Science Societies National Conference, 1-4 July, University of Melbourne.

MacEwan R. J., Gardner W. K., Ellington A., Hopkins D. G. \& Bakker A. C. 1992. Tile and mole drainage for control of waterlogging in duplex soils of south-eastern Australia. Australian Journal of Experimental Agriculture 32, 865-878.

MACUMBER P. G. 1968. Interrelationship between physiography, hydrology, sedimentation and salinization of the Loddon River plains, Australia. Journal of Hydrology 7, 39-57.

McFarlane D. J. \& Cox J. W. 1992. Management of excess water in duplex soils. Australian Journal of Experimental Agriculture 32, 857-864.

NAtHAN E. L. 1998. Dundas landscapes and dryland salinity. MAppSci thesis, University of Ballarat, Ballarat (unpubl.).

NAthan E. L. 1999. Dryland salinity on the Dundas Tableland: an historical appraisal. Australian Geographer 30, 3.

NATHAN R. J., NANDAKUMAR N. \& SMith W. E. 1999. On the application of generalised additive models to the detection of trends in hydrologic time series data. Water '99 Joint Congress pp. 165-172. Proceedings, 25th Hydrology and Water Resources Symposium, Brisbane, 6-8 July 1999. Institution of Engineers, Australia.

NoRTнсоте K. H. 1979. A Factual Key for the Recognition of Australian Soils. Rellim Publications, Adelaide.

NoRthсоте K. H. \& Skene J. K. M. 1972. Australian soils with saline and sodic properties. CSIRO Division of Soils, Soil Publication 27.

PAINE M. D. 1995. Regolith development on the southeastern Dundas Tableland. BAppSci (Hons) thesis, University of Ballarat, Ballarat (unpubl.).
PERRY R. J. 1996. A soil survey of the Bulart region, southeastern Dundas Tablelands. BAppSci (Hons) thesis, University of Ballarat, Ballarat (unpubl.).

Pyne S. J. 1991. Burning Bush. A fire history of Australia. Henry Holt \& Company, New York.

Quinn N. H. 1997. Regolith of the Balmoral 1:100 000 map sheet, western Victoria. BSc (Hons) thesis, University of Melbourne, Melbourne (unpubl.).

RichteR B. C. \& Kreitler C. W. 1993. Geochemical Techniques for Identifying Sources of Ground-Water Salinisation. CRC Press Inc., Boca Raton.

RoBinson N. J. 1999. Soils of the Bulart Land Management Group, eastern Dundas Tablelands. BAppSci (Hons) thesis, University of Ballarat, Ballarat (unpubl.).

SIMPSON C. J. 1996. Eruption history of the Rocklands Rhyolite, western Victoria. Geological Society of Australia Abstracts 41 , 398.

Soll Conservation Authority 1978. The dryland salting problem in Victoria. Review, analysis and proposals. Soil Conservation Authority, Victoria.

SPENCER-JONES D. 1965. The geology and structure of the Grampians area, western Victoria. Geological Survey of Victoria Memoir 25.

STUYFZAND P. J. 1999. Patterns in groundwater chemistry resulting from groundwater flow. Hydrogeology Journal 7, 15-28.

Tennant D., Scholz G., Dixon J. \& Purdie B. 1992. Physical and chemical characteristics of duplex soils and their distribution in the south-west of Western Australia. Australian Journal of Experimental Agriculture 32, 827-43.

Woof C. 1994. Geological and hydrogeological mechanisms of salinisation at Bulart. BAppSci (Hons) thesis, University of Ballarat, Ballarat (unpubl.).

Received 4 August 1999; accepted 27 September 1999 